\title{
Anthropological Aspects of Problem Of God, Faith and Grace*
}

Theology speaks of God, faith and grace on the basis of Revelation. This is the interpretation of the data contained in Scripture and in Tradition. The theologian does not invent new truths, but instead he interprets those, with regard to which he is convinced that they are coming from God. Historical Revelation, however, should not be understood only as a message dictated by God to man. It has become true among people through deeds and words intrinsically connected with each other. Much of its content is available to human reason, and man can learn it easily, with certainty, without any risk of error ${ }^{1}$. Moreover, in some cases Revelation only explicitly states what man knows from his own experience. Hence, for the transmission of faith, a strictly theological argument, explaining the deposit of Revelation, as well as a lecture at the frontier of theology, indicating that the truths revealed are rooted in issues concerning man is of great importance.

This method was used in the Catholic Church less or more clearly in explaining the raison d'être of Christianity. For example, many Fathers of Catholic Church regarded pagan religions as prerequisite for the development of Gospel ${ }^{2}$, and Tertullian directly formulated the thesis that the human soul is Christian by its very nature ${ }^{3}$. This method was used by St. Thomas Aquinas, who often quoted the sentence of Saint Ambrose Omne verum, quocumque dicatur, et

\footnotetext{
STV 14(1976)1.

DV 2-6.

L. Bouyer, Mensch und Ritus, Mainz 1964, 9.

The sentence $O$ testimonium animae naturaliter christianae is in the seventeenth chapter of the work Apologeticus (PL I, 257-536). It is also the main thesis of a separate work by Tertullian (PL I, 609-618). The last one was discussed by S. Szydelski in the article Testimonium animae naturaliter christianae, CT 25 (1954), 178-193.
} 
Spiritu Sancto est, and Saint Bonaventure, when he tried to prove that man is a creature open to God's light ${ }^{4}$.

This method also appears in the dissertations of Erasmus of Rotterdam ${ }^{5}$ and in the modernists' arguments, who however unfortunately tend to draw extreme conclusions on this basis ${ }^{6}$. Eventually, it is present in the Encyclicals of John XXIII Mater et Magistra and Pacem in Terris and in Gaudium et spes.

Contemporary Catholic theology is characterized by an anthropological attitude, based on the assumptions that every question about God is both a question about man and that in the study of structures of being, analysis of the data of consciousness plays a large role ${ }^{7}$. The arguments in this field in most cases consist in demonstrating how Revelation helps to better understand the man. It is as if a top-down approach deriving human truth from the truth of God. It seems, however, that it would be successful to assume the bottom up approach, i.e. deriving what God says about man from what man knows about himself. Certainly, you can consider the revealed content in isolation from the experience data. Since this would entail a risk of formal abstractionism. This statement applies to all theological truths, and in a special way to the problems of God, faith and grace.

\section{The Problem of God as the Basis of Human Existence}

Theology does not deal with proving the existence of God, but demonstrates the rationality of the attitude of faith in God. Hence, it is not without significance, from its point of view, what other fields of study state about God. The problem of the existence of God is even more important for the transmission of faith. Since, the fact of believing, which consists in the acceptance of the message of Christ, presupposes the prior acceptance of the truth that God exists and has manifested Himself in Christ.

Therefore, a significant role in the preaching of the Gospel is played by philosophical arguments for the existence of God, derived either from the

4 E. Gilson, Duch filozofii średniowiecznej, Warsaw 1958, 30; Ib., Historia filozofii chrześcijańskiej w wiekach średnich, Warsaw 1966, 326.

5 E. Gilson, Duch..., op. cit., 31.

6 The mistake of the modernists was not that they sought for the roots of the Christian religion in man, but that they wanted to deduce faith and Christianity from human nature in general. This was taken up by Pius X in the encyclical Pascendi (D 3475-3500).

7 Cf. K. Rahner, Teologia a antropologia, "Znak” 21 (1969), 1533-1551. 
observation of the world (so-called quinque viae), or from the very concept of God (the so-called ontological proof of Saint Anselm) or from the analysis of the human phenomenon itself. It is also important to demonstrate that God exists not only as a Transcendent Being, that is, transcending all creation, but also as an Immanent Being, i.e. existing within us, within our being. Due to this fact, the problem of God becomes necessary for man and is an indispensable reference point with regard to the interpretation of significance of human existence. In turn, Revelation finds its anthropological legitimization in this respect.

The "Five proofs of St. Thomas Aquinas" and the ontological proof of Saint Anselm first and foremost emphasize God's transcendence, His separation from the world and superiority over the world.

Indirectly, therefore, they only explain the existence of a man implicite in his relationship to God. On the other hand, religious studies speak more widely about these relations. The results obtained by them are extremely valuable material for confronting theological theses.

Religious studies confirm that having God's idea at one's disposal can be considered a common phenomenon in case of people. In general, all soundminded people have the idea of God, however they refer to it in different ways, most often either they assume the existence of God or deny it. After all, accepting one or other attitude with regard to the idea of God is something secondary to the idea itself, because it is the result of more or less conscious reflection. Only some theoreticians of religion hold that the idea of God is a subjective concept of a man who has resorted to it either to satisfy certain ideological needs, or because of fear of natural phenomena, or to use it as a tool to restrain freedom and maintain order in class society ${ }^{8}$. It seems, however, that there is a confusion of circumstances with the cause in these explanations. Because the case that gave rise to the idea of God is something different than the circumstances, under which this idea was created. It is true that a man imagined God depending on the environment in which he lived, as well on the degree of culture and knowledge, but this does not determine the source of these ideas.

One question remains, however, unanswered, namely, why, for example, a man thought about God when he saw a clear sky, the power of a rock or the terror of a storm. What prompted him to look for a cause in the non-material, and not, for example, in the material sphere? Natural, sociological or

8 This topic is discussed extensively by Z. Czarnecki in the book entitled Filozoficzny rodowód marksistowskiej teorii religii, Warsaw 1971. Cf. E. Ozorowski, Religia chrześcijańska w aspekcie aksjologicznym, Wiadomości kościelne archidiecezji w Białymstoku 1(1975)2-3, 153-160 (149-174). 
psychological phenomena are not capable of creating the idea of God in man, but only contribute to the fact, that man becomes aware of this idea. The idea of God - as H. de Lubac claims - appears in self-consciousness and imposes itself on the human mind with its very necessity ${ }^{9}$. The Catholic teaching about God also has a common foundation with the issues discussed by the general religious studies concerning sacred. This word (and the others similar to it, e.g. sensus numinis, das Heilige) has become, thanks to numerous recent religious studies, the key to a better understanding of $\operatorname{man}^{10}$.

The term sacred means first of all the moment of separation, isolation, existence different in its nature from the way that the world and man exists, which is the source of fear, horror of man, and which fascinates, attracts, captivates him, gives him satisfaction and makes him happy. This feeling flows from the depths of the soul, where external stimuli are only a condition of its occurrence and never its cause. Sacred is an a priori, non-moral category, independent of facts and history ${ }^{11}$.

It is also important that man finds this otherness in himself and in the world around him and that he feels it regardless of the degree of culture or civilization in which he lives. This indicates a characteristic feature of human existence. Primitive people experienced the sacred on an elementary level, e.g. in atmospheric phenomena, objects (e.g., rock, tree), a distant, separate place. Similar manifestations of the mysterium tremendum, augustum et fascinosum are found in the Bible (e.g. Is 2: 21; 6:6-7; 26:9, Mt 17:4-8; Lk 5:8; Mk 9:5; Acts $17: 1 ; 1$ Cor $3: 22 ; 10: 26)$. The same meaning of sacred is also characteristic of the thought of great Christian mystics, in whose works we find the description of God as the purifying fire, the all-powerful force, the desire and rest of the soul, joy and supreme happiness ${ }^{12}$.

It would seem that contemporary man, mesmerised by the development of technology, lost his sacred dimension. However, this is not the case. For the same man still finds in himself an ahistorical aspect that does not lose itself

$9 \quad$ H. de Lubac, Na drogach Bożych, Paris 1970, 33f.

10 Particularly noteworthy are the following works: R. Otto, Świętość. Elementy irracjonalne $w$ pojęciu bóstwa $i$ ich stosunek do elementów racjonalnych, Warsaw 1968; M. Buber, Ich und Du, Leipzig 1922; Id., God and Evil: Two Interpretations, New York 1963; M. Eliade, Traktat o historii religii, Warsaw 1966; Id., Sacrum, mit, historia, Warsaw 1970; G. van der Leew, Phänomenologie der Religion, Tübingen 21956; M. Scheier, Vom Ewigen im Menschen, Berlin 1933.

11 R. Otto, op. cit., 19.149. Basic information about the sacred in pagan religions and Christianity and the most important literature on the subject can also be found in the article by J. Splett, K. Hemmerle entitled Das Heilige, in: SM, vol. 2 col. 576-582.

12 J. Danielou, Bóg i my, Kraków 1965, 90 f. 
in animality, which goes beyond what is fleeting and mortal, rising up toward a fuller and richer existence ${ }^{13}$. This thesis is confirmed, for example, by human desires, whose object - like the horizon - moves away from man, the more he tries to approach it. The animal satisfies its hunger with material food, while man does not content himself with material well-being, his desires go further. Scholars of religion explain that it is a longing for the lost paradise, the memory of universal sacred archetypes ${ }^{14}$. The church, however, explains that it is anxiety of the heart seeking rest in $\mathrm{God}^{15}$.

Otherness, which is a property of the sacred, is also revealed in what is called a talent or vocation, which a man experiences as something which belongs to him, and at the same time as something in relation to which he experiences numinotic feelings. He cannot, for example, drown out the inner voice, escape from it. He recognizes it as a compelling force, and at the same time he is always happy when he experiences it and follows it. Talent cannot be programmed, at most it can be developed. A vocation is an inner voice, with regard to which a person is aware, that following it is the only true way of living, for his betraying this vocation would surely lead to death ${ }^{16}$.

The sacred trace in man is finally present in the deepest part of man's existence, which distinguishes him from other people and makes him this unique particular man.

One does not need many experiences to conclude that a man, even if he was most similar to other people, and even most connected with them, always remains lonely in certain situations of his life. He feels the presence of this sacred sphere in himself, which is available only to him, a kind of taboo, unattainable to other people. Sometimes this untouchable aspect of himself becomes someone with whom a person begins to communicate. Considering this phenomenon superficially, we find that man talks to himself. And in many cases it is true. After all, a deeper analysis will suggest that the insight into our interiors sometimes becomes an entry into a separate sphere, characterized by a sacred character.

13 M. Eliade, Sacrum... op. cit., 33f.

14 "Russia of balalaikas, romantic East, cinematic Haiti, American millionaire, exotic prince, etc.; in the final analysis - longing for something quite different than the present moment, inaccessible or irrevocably lost, for 'paradise." Ibid., $38 \mathrm{f}$.

15 "The Church truly knows that God himself, whom it serves, responds to the deepest desire of the human heart, which fruits of the earth will never fully satisfy." GS 41.

16 "Rainer Maria Rilke told a young poet who sent him his poems asking for his opinion: Would you have died if you were not allowed to write? If so, continue writing. Otherwise, it's not worth it." B. Bro, Człowiek i sakramenty, Warsaw 1973, 6. 
Theology teaches that this interiorization often becomes the act of discovering God, the experience of the one and only Being who is in power of calling people into existence ${ }^{17}$.

Modern man knows the world better than before. However, this awareness does not eliminate the sacred, at most it allows us to perceive it in different perspective. For example, modern homo technicus is not afraid of a storm, because he invented a lightning rod, he is not afraid of elements of nature, because he can tame them, but he has not got rid of the fear of the unknown, which he sometimes experiences in the most unexpected moments of his life such as a situation of danger. Today's man also knows more precisely the essence of beauty, but at the same time he realizes that beauty cannot be fully understood by means of rigid categories, that being surprising and unpredictable defines its very nature. In addition, man cannot live without religious rites. When he tries to eliminate them, at the same time he introduces the other ones, more or less similar to those of religious nature. On this basis, M. Eliade states that a man, regardless of the degree of desacralization, is not able to free himself from the religious attitude, and the symbols, myths and rituals he propagates always reveal the final situation, i.e. the one which he discovers, when realizing his proper place in the universe ${ }^{18}$. God, of whom Revelation speaks, is also God who is experienced by man within his own being and whose acceptance is necessary to understand the existence of man.

\section{Anthropological Foundation of the Christian faith}

In a similar context one should consider the Christian faith, which consists in the recognition of God's authority, total trust in Him and leading one's life in accordance with this new condition ${ }^{19}$. Theology explains that in the act of faith the mind, will and grace are involved, from which it follows that faith is a gift received from God as well as the decision of man himself. The rationality of faith is related to the question of whether a person behaves rationally when deciding on leading his life faithfully, whether there is room for faith in him and whether it helps him achieve a more complete dimension of humanity.

17 H. de Lubac, Katolicyzm, Kraków 1961, 310f.; R. Guardini, Koniec czasów nowożytnych, świat i osoba, wolność, łaska, los, Kraków 1969, 90; L. Bouyer, op. cit., 82-98.

18 M. Eliade, Sacrum..., op. cit., 51-63; L. Bouyer, op. cit., 82-98.

19 These elements are found in the definition of faith presented during the Second Vatican Council (D 3008). Also DV 5. paid attention to them. 
The answer to the above questions is not simple, because it requires a certain knowledge of God's existence and an understanding of who a man is. The above mentioned arguments for the existence of God confirm the rationality of faith in the sense that they present the real existence of Being, to which man turns in his faith. However, this does not completely solve our problem. Indicating the reason for the existence of faith, it must be justified that it is necessary for man. In the latter case, it should be remembered that faith concerns a very specific sphere of human life. For example, faith is not necessary with regard to shopping or to scientific research. They are autonomic areas, governed by their own rules, while religious faith manifests itself on the occasion of posing the so-called existential questions: why do I exist? for what purpose do I exist? What is the meaning of my existence and the existence of the world? These questions are, moreover, posed by every sound-minded person, which would indicate that they belong to human nature, in the same way as the idea of God does.

Who in that case would be capable of answering these questions? The response will not be provided by the natural sciences that study a specific segment of the world, because such a response would go beyond their competence. However, philosophy may speak on this matter. The latter, however, builds its conclusions on the material provided by the empirical sciences. However, in order to fully answer the above questions, one would have to refer to the categories of infinity and eternity. These concepts are not however the subject of the empirical sciences. In addition, scientific knowledge has limits that it can never fully overcome ${ }^{20}$. It follows that philosophical inference in the field of existential questions posed by man is very close to faith, which - as J. Ratzinger states begins with the acceptance that reality is not exhausted in what is visible and tangible ${ }^{21}$. Faith understood in this way becomes a postulate of a man who, by his very nature, manages to transcend his cognitive limitations.

To oppose science to faith is a misunderstanding since both of them are characterized by their unique specificity. Admittedly science does not exclude faith, and faith does not eliminate science. Similarly, science cannot become faith, and faith cannot be turned into scientific knowledge, because it would imply the loss of specific being by each of them. Besides, faith is not just about filling the gaps of human ignorance. The believer cannot be clearly identified as the one who knows and the unbeliever as the one who does not know. By the fact that faith implies engagement of all spheres of human life,

20 M. Heller, Spotkania z nauką, Kraków 1974, 10.

21 J. Ratzinger, Wprowadzenie w chrześcijaństwo, Kraków 1970, 15. 
it is subject to the laws of crisis and growth. In addition, the Supreme Being as the object of faith is not available to the direct insight of man, hence the acceptance of the Supreme Being depends not only on the mind and will, but also on grace. As a result, man often finds himself in a situation of threat: the believer is exposed to the danger of unbelief, the unbeliever is exposed to the danger of faith ${ }^{22}$.

The anthropological foundation of faith is manifested in the fact that man confronts it as a necessary condition for understanding the world. This is, of course, a reflective understanding, in contrast to a technical one, which is based on quantitative relationships. We know that every being can be considered from these two points of view. Both will be true and equally legitimate. However, understanding, reduced only to grasping numerical proportions, does not exhaust the truth of being. For example, the truth of the table consists not only of the fact that it was made of such and such wood, in such and such style, but also that it can be a family table, gathering around people close to each other, strengthening the family atmosphere. Not only the structure of a given object, but also its creator, the one who made it with a specific intention and its recipient constitute its very truth. Therefore, one cannot achieve the full truth about the world without accepting the existence of the Supreme Being. It is a necessary condition to understand the world, it manifests itself as the necessity of scale, indispensable to be able to measure anything, the necessity of norm, indispensable to be able to evaluate anything and the necessity of point of support, indispensable to be able to make any classification ${ }^{23}$.

Pastoral Constitution Gaudium et spes mentions the following issues, to the comprehension of which faith is necessary: the problem of human nature, the evil existing in the world, death, responsibility, laws governing the human community ${ }^{24}$. Of course, these are not all fields in which faith appears. It can interpret all human history with its tensions between freedom and necessity, immanence and transcendence ${ }^{25}$.

The necessity of faith manifests itself especially clearly when a person is searching for the meaning of life. We know that the concept of the meaning of any instance of existence or any action implies the existence of the rational goal of that existence or action. Although this goal is present in the very nature

22 Ibid., 12

23 H. de Lubac, Na drogach..., op. cit., 39.163; J. Danielou, op. cit., 41.

24 GS 11-23.31.41-42.57.

25 K. Lehmann, Gegenwart des Glaubens, Mainz 1974, 29; Ph. Roqueplo, O trudnościach wiary, Warsaw 1974, 269 
of a given being, it always comes from someone from whom this given being is dependent in its existence, that is, the meaning of being depends on its creator, while man can be regarded as the one who gives meaning to human works.

On the other hand, only the Supreme Being, on whom man depends in his existence, can grant him the sense of his existence and activity. Hence the meaning of human life is not so much the result of knowledge but the result of faith. A man cannot come up with it. He can only accept it as the gift, which has been granted him by the Supreme Being ${ }^{26}$. Faith in such cases becomes a source of meaning, and thus a foundation on which man can base his existence and through which he can survive. There is no selflessness that could stand against meaningless ${ }^{27}$.

Information on what kind of meaning it is can be found in Revelation. Theology deals with it in detail. It must be added here that the latter, when teaching about eternal salvation, does not consider man in isolation from earthly affairs; on the contrary, it states that salvation should be achieved through the daily hardships. Therefore, the allegation that religion can lead to human alienation seems unfounded. Human's hope of heaven, properly understood, is the only thing capable of giving man full passion for earthly work, while faith, by providing man with a vision of a state of ideal living, can contribute to achieving by him a better view of his current condition and thus can prevent him from being uncritically satisfied with himself ${ }^{28}$. However, satisfaction resulting from faith is not easy to achieve. The God of the Bible resists all endeavours of man to control Him and subordinate Him in order to achieve his own interests. He is God who comes to man in the least anticipated moment (Mt 24:43; 1Tess 5:2-3) and He remains distant when man resorts to magic and evades shaping history on his own. Properly conceived faith prescribes man to live in the dialectical tension between transcendence and incarnation, to experience every day in its uniqueness and to find eternity only in the burden of everyday life ${ }^{29}$. Faith gives people a sense of security, but not in the form of a paralyzing illusion or blissful satisfaction, but in form of a certainty that stimulates a person to $\mathrm{act}^{30}$.

26 J. Ratzinger, op. cit., p. $34 \mathrm{f}$.

27 H. de Lubac, Katolicyzm, op. cit., 307.

28 Ph. Roqueplo, O trudnościach wiary, 260-274; H. de Lubac, Na drogach..., op. cit., 166.

29 J. M. Gonzalez-Ruiz discusses this topic in more detail in the article entitled Duchowość na czasy niepewności, Conc. 67(1966)1- 10, 525-532.

30 H. de Lubac, Na drogach..., op. cit., 154. 


\section{Man as a Being Open to God's Grace}

The problem of grace is closely connected with the problem of God, which was mentioned above, but cannot be completely identified with it. For, in the previous case we have only established that man finds in himself and in the world around him the presence of a Supreme Being. This Being is different from the world and a man himself, and this Supreme Being is called God. Here, however, the question whether there is a place in human being for God's free action should be considered. In other words, the problem of the sacred is tantamount to the problem of a human being in its existence, and the problem of grace can be regarded as the problem of a human being in its action.

It is obvious that we have knowledge about grace only on the basis of historical Revelation. We are, however, far from deriving Revelation from the world. Knowing, however, the revealed truths about grace, we discover with amazement their origins in the human being. The biblical concept of grace is closely connected with the question of original sin. The first man turned away from God through his disobedience. This resulted in the loss of those supernatural gifts granted him by God and in serious degradation of human nature. From now on humanity cannot return to God on its own. Thus, every action of God, where restores lost gifts to man, has since then been the effect of the grace. In the Scriptures it determines in the first place who God is with regard to people, then who man becomes, when he accepts the action of God, and finally it indicates the specific gifts, which have been granted man by God ${ }^{31}$. It is, therefore, about the condition of man after committing original sin and about everything that is happening in him, which is not due to his own nature or powers, nor to his obligations or his merits. This action is called supernatural in opposition to the natural one, which is necessary because it arises as a result of certain stimuli or established laws.

The observation of human life confirms that not everything happens in it on the basis of the natural course of things, that there are many unknowns in it that cannot be explained even by the fact of human freedom. Admittedly, there is room for external freedom, higher-order freedom in the social order, within the human being. This thesis is perfectly illustrated by R. Guardini, who sees the elements of grace in human relations based on authority, where the will of a sovereign may suspend the operation of law and in this way compensate for what cannot be predicted in life, then in inspiration and success, which states

31 J. Guillet, Grace, in: Słownik teologii biblijnej, Poznań 1973, 436-441. 
come from as if from the outside, they lie outside of human nature and can only be explained in the context of the entirety of being, then in all kinds of real friendship or love meetings, which often happen as a twist of fate, because they cannot be planned in advance neither determined not calculated, and finally at some moments of extreme euphoria, where one has the impression that the torn existence has achieved its harmony, as well as in experiencing happiness, which is always associated with his awareness of giving to others beyond the measure of his abilities ${ }^{32}$. Everywhere where a man experiences an external endowment, where something results not from a must, prior calculations and planning, but from total freedom, where generosity and magnanimity come to the fore, there are also elements of what is called grace in theology.

Thus, the presence of the grace, understood in such terms, in the world makes it an environment proper to human nature. For man can live to the fullest extent only when he has the power of creativity, when even in the most tragic situations he can count on the revelation of a higher order. Admittedly, the world that is completely determined would become unbearable. Human life, in which there would be no room for contingency would turn out to be a nightmare. There is even a paradox here that law and grace are as if directed towards each other. Law without grace becomes soulless, grace without law turns into a parody. The accused, for example, only then will feel the significance of pardon when he receives it in a situation of final judgment ${ }^{33}$. The necessity of grace with regard to man can be also derived from the fact of who a man really is in relation to his ultimate goal. Phenomenology states that man lives on the verge of what is animal and what is peculiarly human and that he must constantly cross this boundary, otherwise he reduces himself to his animality, which is tantamount to his death ${ }^{34}$. Existential tomism complements these conclusions, claiming that man in his true human existence always aims to achieve higher goals than he can achieve taking into account his human capabilities ${ }^{35}$. It follows that human existence turns out to be a kind of paradox, which can only be understood when accepting the existence of the transcendent Being. Without the supernatural, human life becomes tragic. Grace is what overcomes this tragic dimension and allows man to achieve a goal that he is naturally directed $\mathrm{at}^{36}$.

32 R. Guardini, op. cit., 301-314.

33 Ibid., 302.

34 R. Ingarden, Książeczka o człowieku, Kraków 1973, 13-26.

35 M. Gervais, Nature et grâce chez saint Thomas d'Aquin, LThPh 30 (1974), 333-348.

36 Extensive comments in this regard are contained in the book by A. Zuberbier entitled Relacja natura - nadprzyrodzoność w świetle badań teologii współczesnej, Warsaw 1973, 89-127. 
The awareness of the interrelationships between nature and the supernatural is alive in western theology in the problems of the Paschal Mystery of Christ, and in Eastern theology in the doctrine of theosis. According to the latter, grace can be considered in a sense semi-natural, while nature - theophoric ${ }^{37}$.

$\star * *$

The arguments presented here can be qualified as a part of the more extensive problem concerning relations between the Christian religion and human nature. We have only limited ourselves to paying attention to the essential components of the religious phenomenon ${ }^{38}$. It seems, however, that in the context of all these theological theses and church rites, the question should be posed about how they arise from human existence as well as how they can serve it since only then would their fully anthropological value be fully manifested. What is more, one should refer to a religious phenomenon as such and consider Christianity in its context. Christian religion, in spite of its essential separateness from other religions, shares many common features with them. Christians, therefore consider important the philosophical question of whether religiousness defines man to the same extent as the category homo sapiens, homo socialis, homo faber, etc. does ${ }^{39}$. The problem of the role that religion plays in human life is also significant. Many scholars, for example, emphasize the personality-forming role of religion and its role in maintaining man's mental health ${ }^{40}$.

Man is then the point of reference when proving the raison d'être of the Christian religion. It is not enough to say that the Church comes from God, we must also justify that it is necessary for people.

Similarly, the problem of verification of the Christian religion does not only consist in proving that the present-day Church comes from Christ and that in its historical duration it remains faithful to the will of its founder, but also in justification of the thesis that it represents the value necessary for people.

37 W. Hryniewicz, Teologia prawosławna o przebóstwieniu człowieka; W. Granat, Ku człowiekowi i Bogu w Chrystusie, Lublin 1972, 406-412.

38 The essence of the religious phenomenon is determined by: a) transcendent reality to which man turns, b) attitude towards this reality and c) the effect of this attitude, that is, the active interference of transcendent reality into human life. The Christian religion speaks of God, faith and grace in this respect. Cf. Z.J. Zdybiska, Człowiek i religia, in: M.A. Krąpiec, Ja - człowiek. Zarys antropologii filozoficznej, Lublin 1974, 325.

39 For example, Z.J. Zdybicka agrees that man is a religious being by his nature (article quoted, 315-362).

40 Cf. A. Just, Osobotwórcza funkcja religii, STV 13(1975)1, 157-181. 
Since according to the scholastic principle of verum, it can be considered ens and bonum at the same time. The latter is, however, an anthropological issue.

Also dogmatic and moral theology, not to mention practical theology and theology of internal life, which by their very nature deal with man, is characterized by an anthropological attitude. We have already mentioned that contemporary Catholic theology is strongly inclined towards anthropology. It must be added here that the interests of dogmatics and moral theologians should not be limited to the mere interpretation of revealed truths about man, but should also take into account the confrontation of these truths with the experience of a man about himself. Then the relevance and validity of dogmatic theorems will become clearer and indications of moral theology will become more convincing. 